
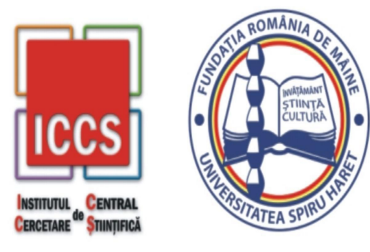

Issue 3/2019

\title{
THE FINANCIAL ACCOUNTABILITY OF E-GOVERNMENT: THE INFORMATION TRANSPARENCY OF DECISION-MAKING PROCESSES IN PUBLIC ORGANIZATIONS
}

\author{
Zenovic GHERASIM ${ }^{1}$, Luminița IONESCU ${ }^{2}$ \\ ${ }^{1}$ Spiru Haret University, Faculty of Economic Sciences, Fabricii Street no \\ 46G, district 6, Bucharest, Tel.: +0040213169783, Fax: +0040213169793, \\ Email: se_zgherasim@spiruharet.ro \\ ${ }^{2}$ Spiru Haret University, Faculty of Economic Sciences, Fabricii Street no \\ 46G, district 6, Bucharest, Tel.: +0040213169783, Fax: +0040213169793, \\ Email: se_lionescu@spiruharet.ro
}

How to cite: GHERASIM, Z., \& IONESCU, L. (2019). “The Financial Accountability of e-Government: The Information Transparency of DecisionMaking Processes in Public Organizations.” Annals of Spiru Haret University. Economic Series, 19(3), 23-32, doi: https://doi.org/10.26458/1931

\footnotetext{
Abstract

Effective e-Government can contribute to the modernization of the public sector administration, and increase the efficiency in the activity of governments and national agencies facilitating the participation of citizens in the social and political life.

The use of e-Government improves the electronic transactions between government agencies, companies and citizens, in order to improve the quality of the services and to increase the transparency in the public financial sector. The recent reforms in the public financial management are accelerated by new technologies and are creating the premises for a disciplined, transpired and flexible public sector administration.

After a presentation of recent views from literature on some main problems of e-Government and software services, the research is focused on the development of e-Government and public finance administration.
} 


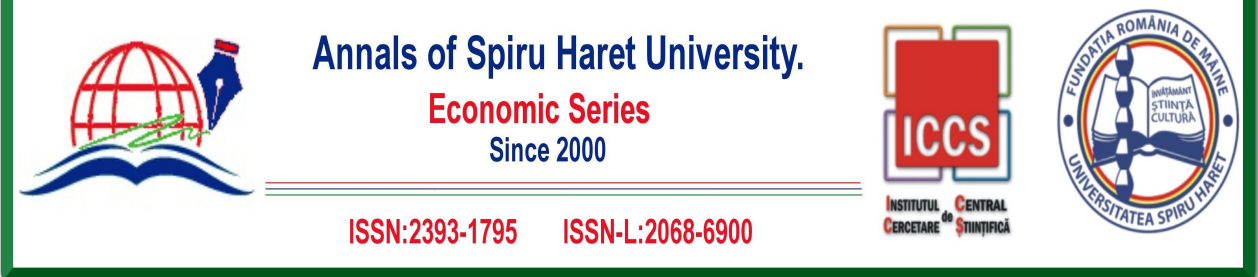

Issue 3/2019

Keywords: e-Government; software services; public administration; financial management

JEL Classification: C88, H83, M48

\section{Introduction}

E-Government is a common concept which defines the use of IT\&C in conjunction with the organizational measures to improve the specific structures, processes and functions of the government. The fundamental forms of e-Government are: G2G (Government to Government), G2B (Government to Business) and G2C (Government to Citizen).

Effective e-Government can contribute to the modernization of the public sector administration, and increase the efficiency in the activity of governments and national agencies facilitating the participation of citizens in the social and political life.

The use of e-Government improves the electronic transactions between government agencies, companies and citizens, in order to improve the quality of the services and to increase the transparency in the public financial sector. The recent reforms in the public financial management are accelerated by new technologies and are creating the premises for a disciplined, transpired and flexible public sector administration.

E-Government provides citizens easy online access to public finance information with economic efficiency and reduced costs.

The next section of the paper presents recent views from literature focused on the specific problems of e-Government and software services, and their influence on the public sector services and public finance administration.

\section{Recent Views From Literature on Some Main Problems of E-Government and Software Services \\ E-Government has a public value, defined as citizens' collective expectations in respect to government and public services [Moore, 1995; Twizeyimana, \& Andreson, 2019]. There are six dimensions of the public value of e-Government: Improved Public Services (IPS); Improved Administrative Efficiency (IAE); Open Government Capabilities (OGC); Improved Ethical Behaviour and Professionalism (IEBP);}




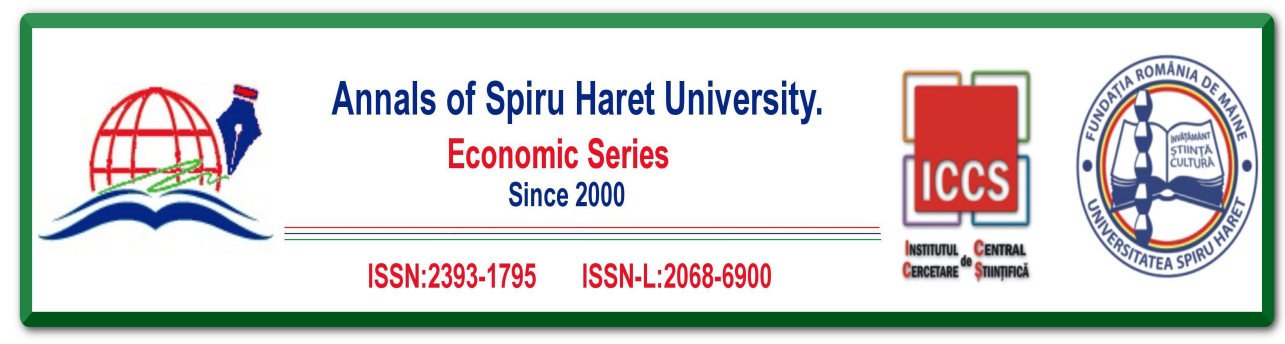

Issue 3/2019

Improved Trust and Confidence in Government (ITCG); Improved Social Value and Well-Being (ISVWB). J.D. Twizeyimana and A. Andreson, (2019) realizes three main dimensions of the public value of e-Government: Improved Public Services, Improved Administration (IAE, OGC, IEBP) and Improved Social Value (ISVWB, ITCG).

The three main domains for e-Government application are e-Administration, e-Citizen and e-Services, and e-Society. There are a lot of sub-domains for e-Government, for examples: e-Finance, e-Education, e-Health, etc. In the domains of the e-Government, it is much better understood and measured online, through appropriated techniques and technologies, fiscal transparency, in conjunction with increased and improved active participation of the taxpayer citizen in e-Government activities and in decision-making.

There is a relationship between the added value and the e-Government projects. In this case, the added value is a public value. The citizen perception on the added value in e-Government determines the decision-making for the new e-Government project. Rather, it is about a perceived value on e-Government projects which highlight the real value of these projects. In fact, the amount invested in IT\&C projects is valued later than the time of investment.

V. Ndou (2004) thinks that the e-Government framework has three main components: transformation areas; users and stakeholders; e-Government application domains. E-Government transformation areas are internal (to improve internal structures, processes and functions of the government), external (to improve transparency to citizen and businesses) and relational (between citizen and state). E-Government users and stakeholders have the following relationships: G2G (Government to Government), G2B (Government to Business), G2C (Government to Citizen) and G2E (Government to Employees). E-Government application domains are e-Administration, e-Citizen and e-Services, and e-Society.

G.P. Simic (2019) considers that e-Government software services depend on a multitude of archived documents. The archived content process prepares all types of documents to the same level of complexity, in different formats (DOC, PDF, ODT, etc.). Useful document content is separated from its formatting part through text filtering and text and metadata extraction from standard document format. There are a lot of software solutions based on grouping the similarly distributed documents. For example, a rule-based inferring software solution allows in English the semantical analysis of the document content.

M.J. Kim (2019) classifies primitive members who need artificial intelligence ethics in intelligent information society in three main categories: developers, 


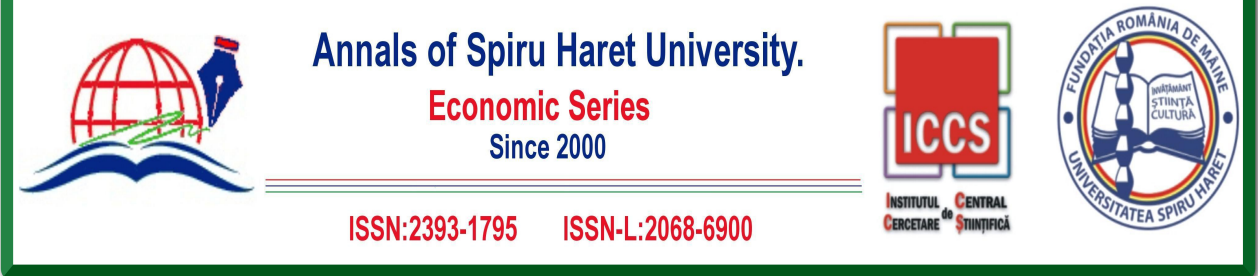

\section{Issue 3/2019}

suppliers and users. Seoul PACT (Publicness, Accountability, Controllability and Transparency) establishes canonical guidelines (for examples, artificial intelligence appliance in e-Government services).

N. Faulkner, B. Jorgensen and G. Koufariotis (2019) propose interventions through several techniques based on the applied behavioural science, to increase citizen numbers which use an e-Government service. Citizens use different channel types in e-Government (web, phone, laptop, desktop, etc). These channels can be integrated with traditional non-digital communication channels to be used in market online service systems including citizen education and training in e-Government.

H. Abualese, T. Al-Rousan, and B. Al-Shargabi (2019) propose a new trust framework for e-Government in Cloud of Things, with the Internet of Things devices, a facile possibility to increase productivity of e-Government services in a trusted manner.

J.B. Lee and G.A. Porumbescu (2019), Wiwik Supratiwi, Isnalita and Farandi Angesti Octorizki (2019) associate citizen participation in government IT\&C training programmes for a good governance with e-Government use. This e-Government use from some citizens may generate new forms of inequity and social exclusion in the future. The duty of governments is to intensively train all citizens so that they can consciously and responsibly use e-Government online services especially from public finance administration.

Cha Sungdeok, (2019) thinks that software programs present bugs because they are made by people who are subject to error, and the software requirements are not always clear or, worse, sometimes are wrong. It is obvious that related software services systems will present periods of malfunction. For example, the ANAF application for collecting state taxes has stalled when a large number of taxpayers have accessed it. Another example is represented by the integrated IT\&C system of the Health Insurance House.

\section{The Development of E-Government and Public Finance Administration}

According to the EU e-Government action plan 2016-2020, a modern and efficient public administration needs to ensure fast and high-quality services for citizens and a business-friendly environment because the digital transformation of government is a key element to the success of the European market in order to promote the macro-fiscal discipline and stability. An important step in the process of public administration modernization is the use of new technology, such as Wide 26 

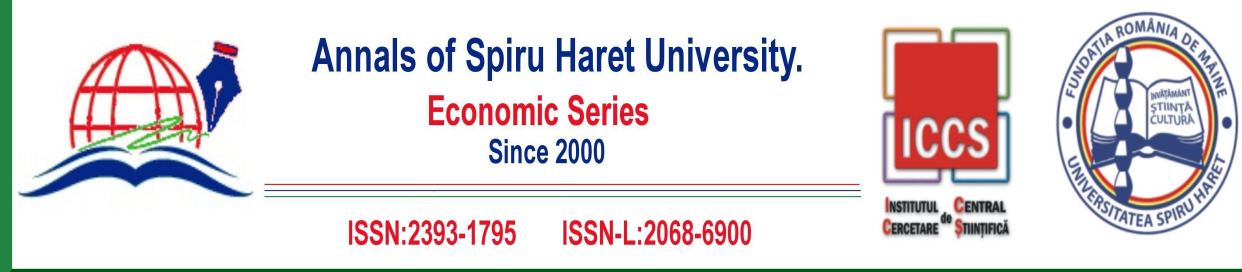

Issue 3/2019

Area Networks, the Internet, and mobile computing [The World Bank, 2012] in order to achieve a much efficient government management.

The use of e-Government in the public finance development has been planned by the European Commission as follows:

Table no. 1. The Steps of E-government in Public Administration

\begin{tabular}{|l|c|}
\hline \multicolumn{1}{|c|}{ ACTIONS } & Target date \\
\hline $\begin{array}{l}\text { 1. Support the transition of Member States towards full e-procurement and } \\
\text { use of contract registers. }\end{array}$ & 2019 \\
\hline 2. Accelerate the take-up of eIDAS services, including eID and eSignature. & 2016 \\
\hline $\begin{array}{l}\text { 3. Ensure the long-term sustainability of cross-border digital services } \\
\text { infrastructure. }\end{array}$ & 2018 \\
\hline
\end{tabular}

Source: www. ec.europa.eu/digital-single-market/en/european-egovernment-action-plan-

$$
\text { 2016-2020 }
$$

In order to understand the steps presented by the European Commission, we need to explain the new technologies in the public finance and public administration, with further actions to accelerate the cross-border transactions. Thus, electronic identification (eID), including mobile ID, and eSignature can facilitate the fast transfer of financial information to the financial agencies and public management. In this way, the results can be less corruption, increased transparency, greater convenience, revenue growth, and/or cost reductions.

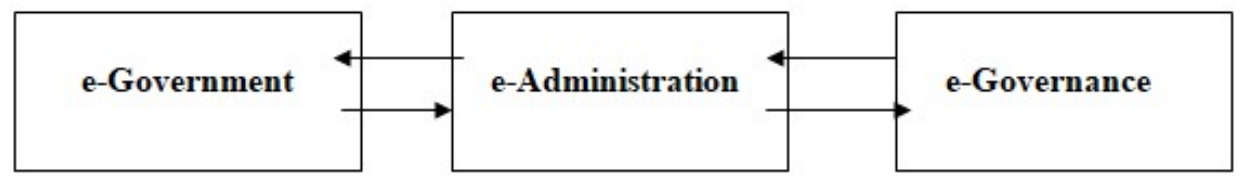

Fig. 1. The Connection between e-Government, e-Administration and e-Governance Source: Authors own work

On long term, the objective of the European Commission is to implement a European Interoperability Framework (EIF) in order to strengthen the interoperability of public services in the European Union. Therefore, to implement 

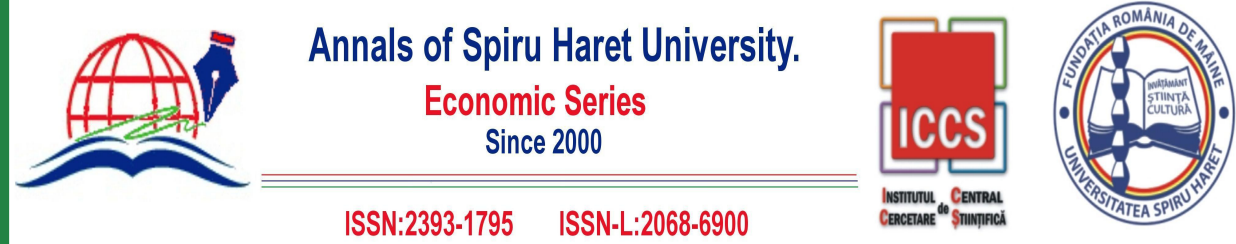

\section{Issue 3/2019}

e-Government in the national public administration for all the European member states, it is necessary to include the concept of "e-Administration" which implies the application of electronic media for the new public management. We could observe below the connection between e-Government, e-Administration and e-Governance.

The development of new political instruments to advance the modernisation of public administrations across the European Union is connected with digital public services in the public sector. According to the EU e-Government action plan 20162020 , by 2020, public administrations in the European Union should be open, efficient and inclusive, providing borderless, personalised, user-friendly, end-to-end digital public services to all citizens and businesses in the European Union. Thus, one of the priorities of Romanian government is to transform the public finance culture and the mechanism of public service from conventional to a modern system, in order to reduce the fraud and corruption. According to World Bank, Romanian government has already taken important steps to improve public financial management, but progress has been uneven.

The principle of transparency concerns the consultation and dialogue with each segment of public administration, as well as civil society, both in terms of substantiating the decision-making processes in the field, as well as the knowledge of events related to corruption. Adopting the digital public services will reduce corruption and bureaucracy in the public sector. Due to the negative externalities of corruption acts, as well as the "public bad" character of corruption, fighting corruption involves the direct and indirect involvement (participation) of a large number of members of society.

The six dimensions of the public value of e-Government in public finance management have associated a lot of Key Performance Indicators - KPIs. These KPIs determine the main action ways in public finance management development and in fighting corruption (fig. 2).

The digital transformation of the public finance has empowered users of the public services and providers and made it possible for them to choose how to access or deliver a public service, how to communicate, when to engage on policy areas or issues, in order to improve the quality of the public service. Finally, the digital technologies will secure, will increase confidence in the public sector and will simplify access to information under EU regulation. 


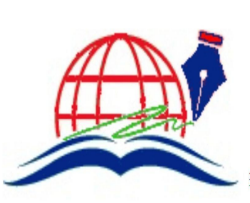

Annals of Spiru Haret University.

Economic Series

Since 2000
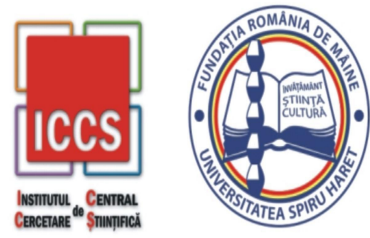

Issue 3/2019

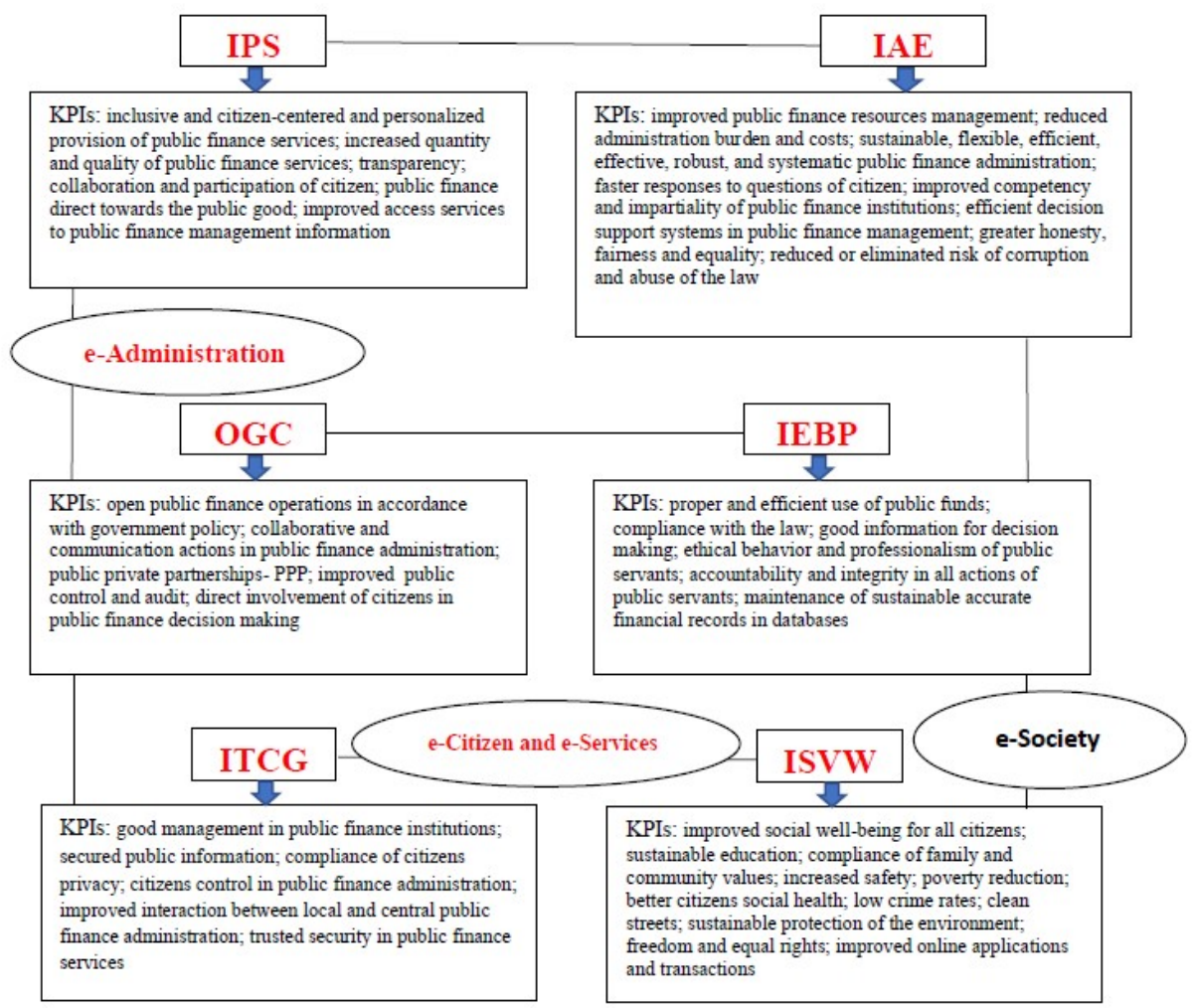

Fig. 2. KPIs for the Six Dimensions of the Public Value of E-Government in Public Finance Management

Source: Authors own work

\section{Conclusions}

In our opinion, e-Government plays a significant important role in economic development in general and public finance in particular. The simplification of the administrative procedures, as a requirement of increasing the efficiency of the public administration on the different levels of economic-social activity, requires the adoption of e-Government. Governments should prioritized using digital technologies 

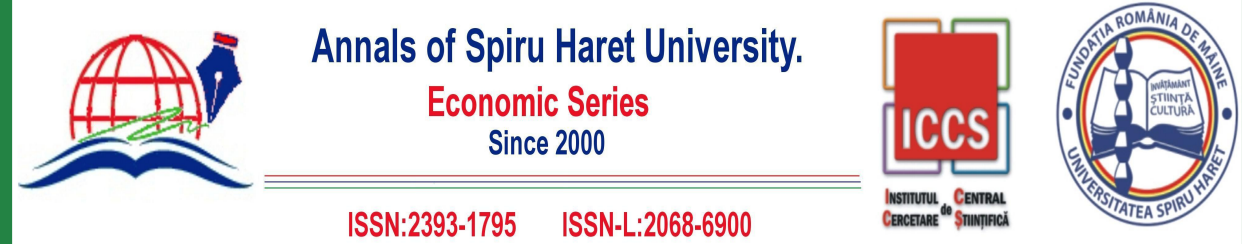

\section{Issue 3/2019}

and e-Government to improve the design and implementation processes of public services and policies in order to meet citizens' and businesses' needs and demands.

The successful implementation of e-Government to public service delivery will first require a change in public sector culture and multi-channel accessibility.

\section{REFERENCES}

[1] Abualese, Hassan; Al-Rousan, Thamer; Al-Shargabi, Bassam, "A New Trust Framework for E-Government in Cloud of Things," International Journal of Electronics and Telecommunications, vol. 65, no. 3, DOI.

[2] Allen, Richard; Hemming, Richard; Potter, Barry (Eds). The International Handbook of Public Financial Management, Palgrave Macmillan, USA and UK, 2013.

[3] Faulkner, N., Jorgensen, B., Koufariotis, G., (2019), "Can Behavioural Interventions Increase Citizens' Use of E-Government? Evidence from a Quasi-Experimental Trial," Government Information Quarterly, vol. 36, www.elsevier.com/locate/govinf.

[4] Gherasim, Zenovic (2006). "Particularităţi ale securităţii bazelor de date utilizate în afacerile electronice pe Internet," Analele Universităţii Spiru Haret, Seria Economie, Nr. 5.

[5] Gherasim, Zenovic; Ionescu, Luminiţa (2019). "E-Governemnt and Public Financial Management," Volumul Conferinței E-Governance and E-Justice in the Space of Freedom, Security and Justice of the European Union, iunie 2019, Facultatea de Drept şi Administraţie Publică Bucureşti, Universitatea Spiru Haret.

[6] Ghiorghiţă Eugen; Gherasim, Zenovic (2010). "Tendinţe în dezvoltarea e-Government la nivel macroeconomic," Volum cu lucrări A-XVIII-a Sesiune de Comunicări ştiinţifice a cadrelor didactice, Universitatea Spiru Haret, Facultatea de Contabilitate şi Finanţe Rm.Vâlcea, 16-17 Aprilie.

[7] Guangwei, H., Jiaqi, Y., Wenwen, P., Sohail, R.Ch., Liu, L. (2019). The Influence of Public Engaging Intention on Value Co-Creation of E-Government Services, IEEE Access, vol. 7.

[8] Guth, Stephen, Contract Negociation Handbook: Software as a Service, $1^{\text {st }}$ Edition, Guth Venture L.I.C., Alexandria, Virginia, USA, 2013.

[9] Ionescu, Luminiţa (2015). "The Role of e-Government in Curbing the Corruption in Public Administration," Journal Economics, Managements and Financial Markets, Addleton Academic Publishers, New York, 10(1).

[10] Isnalita, Supratiwi, W.; Octorizki, Farandi A. (2019). The Role of Good Government Governance on the Influence of e-Government Implementation Toward Local Government Performance, 3rd International Conference on Economics, Education, Business and Accounting, volume ICEEBA, KnE Social Science, DOI. 

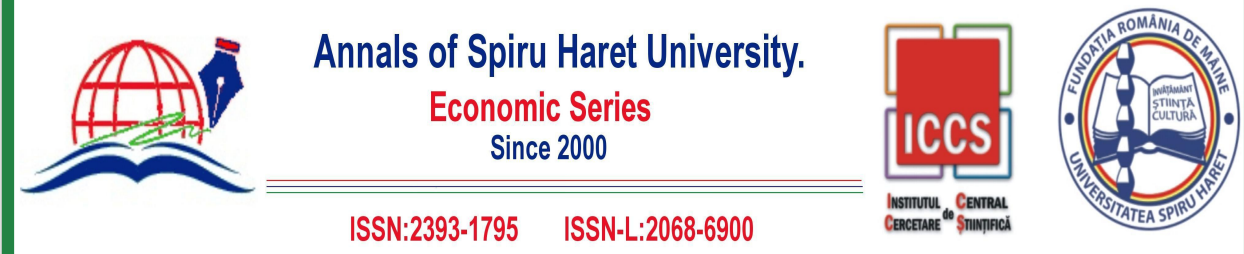

Issue 3/2019

[11] Kim, Myuhng Joo (2019). "Seoul PACT: Principles of Artificial Intelligence Ethics and its Application Example to Intelligent E-Government Services," Journal of Information Technology Services, vol. 18, no. 3, Abstract.

[12] Lee, J.B., Porumbescu, G.A. (2019). "Engendering inclusive e-Government use through citizen IT training programs," Government Information Quarterly, vol. 36, www.elsevier.com/locate/govinf.

[13] Manoharan, A., E-Government and Websites. A Public Solutions Handbook, Routledge, Taylor \& Francis, New York and London, 2015.

[14] Muthucumaru, M.; Elarbi, B., (Eds). Handbook of Smart Cities: Software Services and Cyber Infrastructure, $1{ }^{\text {st }}$ Edition, Springer, Switzerland, 2018.

[15] Nedeljkovic, S. (2019). "An Advanced Quick-Answering System Intended for the eGovernment Services in the Republic of Serbia," Acta Polytechnica Hungarica, vol. 16, no. 4.

[16] Ndou, V. (2004). "E-Government for developing countries: Opportunities and challenges," The Electronic Journal of Information Systems in Developing Countries, No. 18.

[17] Nica, Dumitru; Ionescu, Luminiţa, Evaluarea întreprinderii şi diagnostic financiarcontabil, Editura Fundației România de Mâine, București, 2019.

[18] Przeybilovicz, E.; Cunha, M.A.; Meirelles, F.S. (2018). "The use of information and communication technology to characterize municipalities: who they are and what they need to develop e-Government and smart cities initiatives," Brazilian Journal of Public Administration, Rio de Janeiro, July-Aug.

[19] Simic, G.P. (2019). "Improving e-Government Services for Advanced Search," Vojuotechniki Glasnik, vol. 67, Issue 2, web.a.ebscohost.com.

[20] Stoica, O. (2015). E-Government Implementation in Romania. From National Success to International Example, www.academiaedu.ro.

[21] Sungdeok, C.; Richard, T.; Kyochul, K. (Eds), Handbook of Software Engineering, Springer, Switzerland, 2019.

[22] Twizeyimana, J.D. (2019), The Public Value of E-Government - A Literature Review, Government Information Quarterly, vol. 36, www.elsevier.com/locate/govinf.

[23] www.e-licitatie.ro

[24] www.licitatiiseap.ro

[25] www.anaf.ro

[26] www.cnas.ro

[27] www.ghiseul.ro

[28] www.mcsi.ro

[29] www.academiaromana.ro 


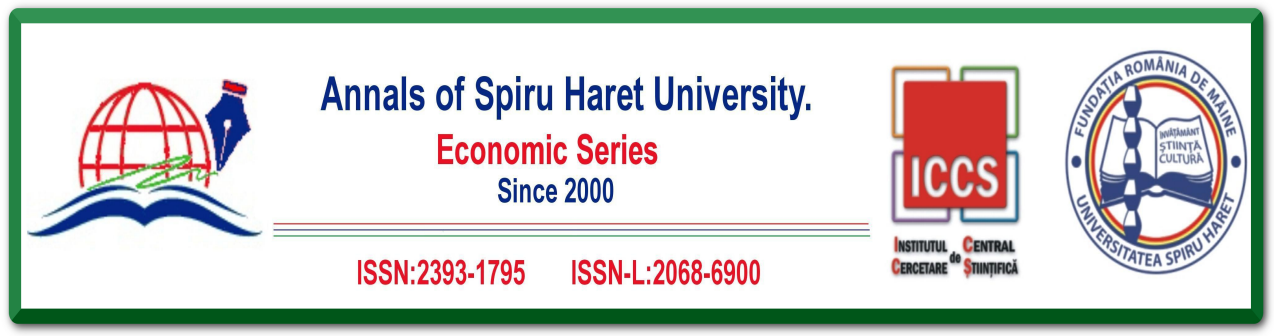

Issue 3/2019

[30] www.insse.ro

[31] https://ec.europa.eu/digital-single-market/en/european-egovernment-action-plan-20162020

[32] https://ec.europa.eu/info/system/files/2015-european-semester-annual-growth-surveyen.pdf

[33] http://ec.europa.eu/priorities/jobs-growth-and-investment_en 